\title{
A DESIGNAÇÃO DE LÍNGUA: SENTIDO, ARGUMENTAÇÃO E O TEXTO NO CIBERESPAÇO
}

\author{
Autora: Claudia Freitas Reis \\ Ano de defesa: 2015 \\ Orientadora: Eduardo Roberto Junqueira Guimarães \\ Instituiçẫo: Universidade Estadual de Campinas
}

A tese propõe um estudo semântico-enunciativo em torno da pergunta qual a designação da palavra "língua" em textos postados no site da UNESCO? Em busca desta resposta, ancorados teoricamente nos conceitos da Semântica do Acontecimento, é feito um percurso que discute, pela relação que se coloca com nosso corpus de estudo, primeiramente, a questão do espaço de enunciação que nos permite pensar na relação entre línguas afetadas pelo político e a consideração da Internet enquanto um espaço de enunciação que nos possibilitará pensar, posteriormente, o funcionamento do texto no ciberespaço pelo viés enunciativo. Esta questão se delineia não somente por uma construção teórica, mas, sobretudo, pelas análises que desenvolvemos, as quais nos levam para além de uma designaçáo da palavra: permite-nos esta aproximação e o convite ao deslocamento teórico no tratamento do texto. É justamente este deslocamento que articula nosso estudo à questão proposta no dossiê: de que forma nosso dispositivo teórico nos permite pensar na produção do texto digital. Outra questão importante sobre a qual nos debruçamos é a reflexão sobre a tradução e a proposta de democratizaçáo linguística enunciada e materializada no site. Por conta do nosso percurso, discutimos o conceito de língua na Linguística; pela Antropologia apresentamos formulaçóes sobre a relação entre língua e cultura. Discutimos também a questão da divulgação científica e do lugar da Linguística enquanto a ciência da linguagem pelo modo como é significada nos textos analisados. Todo o percurso serve de base para nossas descrições na construção do domínio semântico de determinação (DSD) da palavra estudada, sustentando e guiando nossas articulaçôes interpretativas. Nossas conclusóes nos levaram a perceber, dentre outras coisas, a escassez de ocorrências da palavra língua isoladamente e, por esta razão, a olhar para as formaçōes nominais como língua(s) materna(s), língua(s) indígena(s), língua(s) em perigo. Como resposta à pergunta "o que é língua?", vimos que esta é marcada por uma heterogeneidade na designação, decorrente do 
funcionamento enunciativo e por um apagamento da ciência no tratamento das questôes linguísticas. Com estas análises, demonstramos o funcionamento argumentativo que sustenta as açóes propostas pela Organização, pautadas no argumento da preservação e da circulação das línguas. Tomando a questão do discurso digital, poderíamos dizer que uma das contribuiçóes mais relevantes da tese foi a possibilidade de refletir, a partir de nosso lugar teórico, sobre o funcionamento do texto no ciberespaço, com vistas à configuraçáo do site. Este interesse foi aguçado, primeiramente, pelo fato de termos palavras que marcavam links, ou seja, tomados pelo próprio lugar de uma semanticista que busca estudar o sentido de uma palavra, fomos levado a dar consequência à relação palavra/link. Em segundo, o fato dos links possibilitarem as camadas que fazem funcionar a hipertextualidade. A partir desta problemática em particular, realizamos uma série de análises do que chamamos de esquema de linkagem guiados pela questão: de que maneira a disposição dos links afetaria o estudo da designação? De que maneira os links partiam ou integravam os textos? Como, entâo pensar no texto neste espaço? Considerando que os links vão construindo enumeraçôes, pudemos tratá-los pela forma como reescreviam o "tema", ou seja, o enumerado, e considerar como funcionavam as articulaçóes nestes processos de reescritura. Neste sentido, pudemos produzir dois conhecimentos importantes: as especificidades de se pensar o texto neste espaço a partir do seu funcionamento e o funcionamento enunciativo da enumeraçáo pelo estudo dos links. 